\title{
Persuasive Communication in a Healthy Lifestyle Campaign in Pandeglang District (Case Study of Arisan Jamban Program)
}

\begin{abstract}
Abdul Malik
Communication Department, Universitas Serang Raya, Indonesia kangdoel2002@gmail.com

\section{Liza Diniarizky Putri}

Communication Department, Universitas Serang Raya, Indonesia i_jupri@rocketmail.com
\end{abstract}

E-ISSN (2721-0642)

Recieved:

June 272020

Revised:

July 282020

Accepted:

August 32020

Doi Number

10.37950/ijd.v2i2.62

\begin{abstract}
Since 2007, the Amil Zakat Harapan Duafa Institute (LAZ Harfa) has actively initiated a healthy life movement campaign in the Pandeglang Regency, especially to people who are still practicing open defecation (BABS), due to either the lack of latrines or other factors. "Jamban" in English means latrine. Using the Community Lead Total Sanitation (CLTS) method, this healthy living campaign is focused on the latrine ownership program through the arisan system. An Arisan is a form of rotating savings in Indonesian culture. From the results of research using case studies, this healthy living movement campaign has brought significant results. Through a persuasive communication process as part of the approach to the community strategy, the results were obtained that by the end of 2019 as many as 29 assisted villages in 8 sub-districts in Pandeglang District had been free from the practice of open defecation. This fact shows that the persuasive communication carried out in this healthy living campaign is quite effective and brings the expected results.
\end{abstract}

Keywords: persuasive communication, healthy living campaigns, CLTS, arisan jamban 


\begin{abstract}
Abstrak
Sejak tahun 2007 silam, Lembaga Amil Zakat Harapan Duafa (LAZ Harfa) aktif melakukan inisiasi kampanye gerakan hidup sehat di wilayah Kabupaten Pandeglang, khususnya kepada masyarakat yang masih menjalankan kebiasaan membuang air besar sembarangan (BABS), baik karena ketiadaan jamban ataupun karena faktor lain. Menggunakan metode Community Lead Total Sanitation (CLTS), kampanye hidup sehat ini difokuskan pada program kepemilikan jamban melalui sistem arisan. Dari hasil penelitian dengan menggunakan studi kasus, kampanye gerakan hidup sehat ini telah membawa hasil yang disignifikan. Melalui proses komunikasi persuasif sebagai bagian dari strategi pendekatan kepada masyarakat, diperoleh hasil bahwa hingga akhir 2019 sebanyak 29 desa dampingan di 8 kecamatan di Kabupaten Pandeglang telah terbebas dari kebiasaan BABS. Fakta tersebut menunjukkan bahwa komunikasi persuasif yang dilakukan dalam kampanye hidup sehat ini berjalan cukup efektif dan membawa hasil sebagaimana diharapkan.
\end{abstract}

Kata Kunci: komunikasi persuasif, kampanye hidup sehat, CLTS, arisan jamban

\title{
Introduction
}

One serious problem regarding healthy living behavior in Pandeglang is the habit of the people who defecate carelessly (BABS). In addition to the lack of latrines (Jamban) in their homes, this behavior is triggered by habits that have been passed down for generations due to both economic factors (read; poverty), ignorance, and lack of knowledge of the importance of health due to low levels of education.

In Pandeglang District there is currently around 50 percent of households that are declared not to have fulfilled healthy lifestyles. Of 282,678 households, 141,339 households were categorized as unhealthy houses (https:/ / bantenheadline.com/ratusan-ribu-rumah-tangga-di-pandeglang-masihdolbon/ Accessed Wednesday 29 April 2020 at 10.20).

One indicator of unhealthy houses is the absence of latrines. For this reason, people who generally live and live in rural areas defecate carelessly, whether done in the forest, gardens, bushes, tree roots, river banks, or other places that they value are safe. BABS behavior or open defecation is popularly called "dolbon", short for Modol in Kebon, which means defecating in the garden. That is a behavior which is very far from healthy living behavior.

BABS habits, in addition to causing an unhealthy residential and residential environment, also lead to the emergence of various diseases that are often suffered by the community. Among others are diarrhea and other comorbidities. Also, the habit of BABS reflects the condition of public health. Based on available data and facts, in most of the people who behave in unhealthy lives, many health problems are found. Starting from babies with malnutrition and stunting, tuberculosis, and so on.

In Pandeglang District there are currently at least 845 children under the age of five (toddlers) who suffer from malnutrition. While of as many as 150,377 toddlers, 4,310 of them experienced dwarf growth or stunting. Besides being caused by wrong parenting, the lack of access to nutritious food, sanitation, as well as 
environmental health and clean water also causes health problems in the community. People with severe malnutrition in Pandeglang are also accompanied by accompanying diseases such as tuberculosis, mental disability, and diarrhea as a result of poor sanitation and lack of clean water, which is exacerbated by open defecation culture. (Https://banten.idntimes.com/news/banten / khaerul-anwar-2 / descend-4310-toddler-in-pandeglang-still-natural-stunting / full Accessed Wednesday 29 April 2020 at 10.35).

Efforts to build awareness to the community to carry out healthy living behaviors by not continuing to defecate openly (BABS) are done continuously, not only by the local government but also by various non-governmental organizations. One of the efforts is done by the Amil Zakat Harapan Dhuafa Institute (LAZ Harfa). Since 2007, LAZ Harfa has been actively educating people in various villages in Pandeglang Regency about the importance of healthy living. In addition to providing assistance and persuasively continuing to campaign for the importance of healthy living, this institution has succeeded in making a breakthrough in overcoming sanitation problems and BABS habits, namely by carrying out social campaigns for healthy living through the Community Lead Total Sanitation (CLTS) program in the form of arisan jamban. Arisan is a form of rotating savings in Indonesian culture, in this case, Latrine (jamban) is the target that wanted. As a result, more than fifty thousand Pandeglang residents under the guidance of Laz Harfa have succeeded in changing their behavior, from dolbon to latrines.

The success of LAZ Harfa in conducting a healthy living campaign through the arisan jamban program is also a form of the success of the institution in carrying out social change movements. In this perspective, LAZ Harfa as an institution that initiates a change agenda called an agent of change, while the form is called planned social change. It involves input, process, and output, as phases of change.

Input in the context of social change can be called a program or planned activity to be implemented. The process in the context of social change and development is the implementation of the activities program that has been previously formulated. While the output can be referred to as the results obtained from the input and the process carried out. In each phase of the changes carried out from input to process, to output - always involves planned communication processes.

Planned communication processes that are contained in each phase of the planned change are also called communication strategies. Called by Rogers (in Cangara, 2014: 61) as a design that is structured to change human attitudes and behavior on a larger scale through the transfer of new ideas.

However, in general, every change that takes place in the community always requires a process communication in it, planned or not. In the context of social change Hoveland (in Wuryanto, 2014: 6) defines communication as The process by which the individual (the communicator) transmits stimuli (usually verbal symbols) to modify, the behavior of other individuals (Communication is the process by which individuals transmit stimulus to change the behavior of other individuals).

That the agenda of social change (social change) can not be separated from the communication process, following the two functions of communication proposed by Pearson and Nelson (in Mulyana, 2003: 5). First, for our survival, which includes physical safety, increasing personal awareness, presenting ourselves to others, and 
achieving personal ambition. Second, for the survival of the community, precisely to improve social relations and develop the existence of a community. Based on these two functions, communication in the context of social change and development is part of efforts to survive, improve social relations, and develop the existence of a society. In this case, communication is a bridge that connects and at the same time fosters the social system of the community in their efforts to make changes.

Due to the planned nature of the change, the communication used in this latrine ownership campaign was also planned, strategic, and persuasive. This type of communication is even commonly used in every campaign carried out by various parties. In addition to be informative, campaigns also usually contain invitations, even persuasions, to the intended audience or parties to take the action or action as expected. Therefore, the nature of such communication is also referred to as persuasive communication.

More specifically, a campaign is a series of planned communication actions to create a certain effect on a large number of audiences that are carried out sustainably over a certain period (Rogers and Storey in Venus, 2009: 7). The persuasive communication can be interpreted as a symbolic process in which communicators try to convince others to change their attitudes or behavior about the problem through the transmission of messages in an atmosphere of free choice (Richard M. Perloff in Ruslan, 2008: 27). Or, it can also be interpreted as an act of communication that aims to create an audience adopting a communicator's view of something or taking a certain action (Wayne R. Pace, Brend D. Peterson, and M. in Ruslan, 2008: 27).

Related to this problem, this study is focused on answering the problem formulation of how persuasive communication carried out by LAZ Harfa in the healthy living campaign through toilet arisan programs in Pandeglang Regency, from planning (input), implementation (process), to the results obtained (output).

\section{Theoretical Framework}

\section{Communication for Social Change}

The social change agenda will not run and get maximum results without the communication process that is built and created by the actors (actors) and stakeholders in it. Where the nature of communication in the context of social change is an effort to change attitudes or behavior as expected from these changes.

That the agenda of social change can not be separated from the communication process, following the two functions of communication proposed by Pearson and Nelson (in Mulyana, 2003: 5). First, for our survival, which includes physical safety, increasing personal awareness, presenting ourselves to others, and achieving personal ambition. Second, for the survival of the community, precisely to improve social relations and develop the existence of a community. Based on these two functions, communication in the context of social change and development is part of efforts to survive, improve social relations, and develop the existence of a society. In this case, communication is a bridge that connects and at the same time fosters the social system of society in their efforts to make changes.

Goran Hedebro (in Nurudin, 2007: 46-47) mentions that there are at least four communication functions in social change, namely:

1. Communication implies the exchange of messages. So, there is no change in 
society without communication.

2. Communication is only one of many factors that can cause social change.

3. The media used in communication have a role in legitimizing existing social buildings. It forms the consciousness that determines people's perception of the world and the society in which they live.

4. Communication is an extraordinary tool for overseeing one of the important strengths of society; mental conceptions that shape people's insights about life. In another sense, those who are in a position to oversee the media can exert decisive influence in the direction of social change.

\section{Campaign and Persuasive Communication}

Rogers and Storey (in Venus, 2009: 7) define a campaign as a series of planned communication actions to create a certain effect on a large number of audiences that are carried out continuously over a certain period.

Charles U Larson (in Ruslan, 2005: 25-26), divides the campaign into three types. First, product-oriented campaign. Namely campaign activities that are oriented to the introduction or sale of a product and are commercial in nature. Second, ideological or cause-orientedcampaigns. Namely the type of campaign that is specifically oriented and has the dimension of social change and is usually noncommercial. Third, candidate-oriented campaigns. Namely the type of campaign to introduce or popularize candidates who are oriented to politics and power.

Because of the planned nature of communication, communication in every campaign is generally persuasive. This type of communication is needed to move people to want to change their attitudes and behavior as expected by the communicator. Simon (in Dainton and Zelley, 2004: 104) defines that "persistence is typically defined as human communication that is designed to influence others by modifying their beliefs, values, or attitudes".

In line with this definition, Richard M. Perloff (in Ruslan, 2008: 27) defines persuasive communication as a symbolic process in which communicators try to convince others to change their attitudes or behavior about problems through message transmission in an atmosphere of free choice. Likewise, Wayne R. Pace and Brend D. Peterson (in Ruslan, 2008: 27) defines persuasive communication as an act of communication aimed at creating audiences adopting a communicator's view of something or taking a particular action.

Based on various definitions of persuasive communication as mentioned above, it is concluded that persuasive communication is oriented towards changing attitudes, beliefs, and behavior. Attitude can be interpreted as a tendency to behave in certain ways. In this case, it can be further explained that the nature of persuasive communication is the tendency to change a person's attitude caused by exposure to information conveyed by the communicator of change. The targets for changing attitudes include affective aspects (liking or feeling towards an object), cognitive (belief in an object), and motor (behavior or actions towards an object). Trust is a sense of confidence or belief in something regarding the truth. Trust arises due to both observations and experiences, as well as facts related to the truth from others, while behavior refers to clear and observable actions, or also called the action on someone's attitude towards something. 


\section{Research Methodology}

This research was conducted based on a qualitative approach, thus allowing researchers to discuss this research more broadly and in-depth. While the problems in this discussion are categorized as case study studies because they have unique characteristics. Where the subject of the study in this case study is how persuasive communication is carried out by LAZ Harfa in a healthy living campaign through an arisan jamban program in Pandeglang Regency, from planning (input), implementation (process), to the results obtained (output).

The type of case study in this research is instrumental case studies, namely as stated by Stake (in Denzin, 2005: 445-446) that the problem is deliberately examined to gain an understanding of an issue or to get generalizations so that it is as a support and clarify other cases.

Following qualitative research procedures (Bogdan \& Taylor in Moloeng, 2007: 3), the nature of the data in this study is descriptive in the form of written and oral words of people or observed behavior, both based on data documentation, observation, and interviews with sources related to the object of research.

\section{Result and Discussion Planning}

Community Lead Total Sanitation Program (CLTS) is a health program that aims to help people behave in healthy lifestyles by not defecating openly or BABS. This program was adopted from a movement that was first carried out in Bangladesh, with an innovative method that mobilizes the community to eliminate the behavior of BABS. In this case, CLTS has the principle that providing toilet facilities for the community does not guarantee its use, nor does it cause changes in hygiene behavior or increase sanitation access (Percik, 2012: 8).

This arisan jamban-shaped program has been implemented by LAZ Harfa since 2007, focused on villages or villages where the community identified as still practicing open defecation due to lack of latrines and other factors. Among them are in Bulakan Village, Kutamekar Village, and Bahbul Village, Kertaraharja Village. Both are in the Sobang District, Pandeglang Regency.

Since 2014, the two villages have been included in the Community Lead Total Sanitation (CLTS) program initiated by LAZ Harfa. This program was intentionally initiated as a form of concrete action to create healthy sanitation. More specifically, the arisan jamban program aims to increase public awareness and awareness of the importance of clean and healthy sanitation.

Geographically, the two villages are located in an area that is still isolated. Access road still consists of stone and gravel. While the majority of the population are farm laborers with minimal and uncertain income. Almost all houses in the two villages are not equipped with latrines, and therefore the community is accustomed to defecating in the garden. To break the chain of the habit of BABS, LAZ Harfa initiated CLTS program in which the form of activities is arisan jamban.

Before the program was rolled out, various approaches had been made to both village officials, community leaders, and directly to the community. In addition to providing education about the importance of healthy lifestyles, the approach is also carried out as an effort to identify various factors that lie behind the absence 
and unwillingness of people to defecate through latrines. Such education and outreach are not only done formally by presenting village officials and formal places such as village halls but also through informal meetings and cultural gatherings in people's homes such as religious studies and other religious events.

Furthermore, the concept of a movement called arisan jamban, which is a toilet ownership movement for every house carried out by arisan, is offered to the community. Technically, the community periodically collects the agreed amount of money to the designated group leader to determine who gets the toilet. Thus, in turn, each house will have a toilet, so that the change in behavior towards a healthier life can be realized.

However, it is not easy to realize the movement. The BABS habit factor that has become so entrenched, poverty, plus a lack of understanding of healthy lifestyles, is the biggest obstacle faced. For this purpose, various approaches continue to be carried out, both personally to each community, as well as structurally to the village apparatus and community leaders, including group approaches, both by age and sex.

One attempt to approach the community is to use the 'brainwashing' method. Also called the triggering method. That is a method used for the purpose of changing hygiene and sanitation behavior through community empowerment. In this case, the community is said to be "triggered" when they are aware and committed to change their behavior, so they immediately take the necessary followup.

Through this method, citizens are persuasively given an understanding of how they should reflect, do reflection and evaluation related to the habits of BABS. Not done by patronizing, but through communication that is so persuasive, where residents are invited to gather in a friendly atmosphere, then asked to draw a map of their village on wide paper that had been prepared previously. Next, on the map, they were asked to draw the location of each home complete with religious facilities and fields, gardens, or rice fields.

Residents are then asked to put yellow objects made of a kind of cake batter, to locations where they often defecate. After all, the residents will be asked to pay close attention as well as to imagine their dirty and disgusting living environment because it is full of their filth.

Through the 'brainwashing' method that's how people are built to be aware of their old habits, it is BABS. In that situation, residents are then given an understanding of the health hazards arising from unhealthy environments due to the habit of BABS. Starting from the emergence of various infectious diseases such as diarrhea and dysentery, tuberculosis, polio, and so on, to a dirty environment.

The persuasive communication patterns adopted in the 'brainwashing' method are quite effective in triggering and whipping citizens' awareness. Generally, every time the brainwashing method is carried out, the process will immediately appear attitudes, behaviors, or conscious responses that the habit of BABS is a habit that is wrong, inappropriate, even disgusting. Among others, it can be seen from the facial expressions that imply disgust when imagining the stool droppings are drunk because their water source has been polluted. There is also a consciousness that arises, sudden nausea or vomiting after imagining the negative effects arising from BABS. 


\section{Implementation}

To keep the awareness of residents after the brainwashing method implemented it was maintained, LAZ Harfa and the volunteers deployed continued to intensify the assistance. These volunteers even jumped in and mingled with the community for 24 hours. In addition to being more intimate, the presence of volunteers is considered important as an effort to continue to educate as well as provide motivation to the community, so that their enthusiasm and awareness to make changes to a healthier lifestyle, namely by not defecating not slacking. From a communication perspective, these volunteers are social change communicators who do work, both as motivators and facilitators.

These volunteers are the spearhead of the toilet arisan movement. In addition to raising awareness for the community through various communication patterns, both personally and in groups, and by using a variety of mediums, these volunteers also facilitate the formation of arisan groups whose participants are mothers. Not only were they asked to deposit several funds periodically for the benefit of toilet latrines, but through informal meetings that took place periodically, it was also built awareness to at the same time improve living standards through the formation of microfinance groups, namely a kind of savings and loan cooperatives that could be utilized as their business capital, including the program for the provision of clean water facilities and the program for the use of yards for food security.

Thus, not only did they get the latrines, but they also grew awareness to improve their standard of living. The proverbially rowing of two or three islands was successfully surpassed, apparently giving a sufficient explanation of the effectiveness and positive impacts obtained from this program. Because, through this arisan jamban program, the community is not only able to change the bad habits of open defecation that have positive implications for healthy living behavior and the creation of a clean environment, but also have implications for improving their well-being.

In its implementation, the arisan jamban which was initiated by LAZ Harfa is guided by the four basic principles of the CLTS program. The four principles are; First, arisan is done without subsidies. This means that people without exception must pay a social gathering every period. This was done to emerge a spirit of independence from each participant. Second, program socialization and education are done without patronizing, not coercing, including not promoting certain types and brands of latrines. In this case, all decisions, both the amount and amount of contributions, as well as the type and form of latrines, are left entirely to the arisan participants. The most important thing is that the target for each house to have a toilet can be fulfilled so that the habit of open defecation can be broken immediately. Third, make the community a leader. As for the existence of volunteers, they play more of a role as facilitators and facilitators. Therefore, volunteers do not make any policies and decisions related to this program. The initiation of toilet procurement and making, including the pattern and method of arisan gathering, was entirely decided by the participants themselves. They are the stakeholders and decisionmakers. Fourth, the community is involved in analyzing problems and potentials, planning, implementing, utilizing, and maintaining them. 
Therefore, since the program was introduced to completion, LAZ Harfa as the program initiator did not issue any financial assistance. The policy of not providing this assistance is following the CLTS concept, which is to build awareness and independence. It is the people who consciously strive and try themselves to fulfill everything that is needed. For example, in Bahbul Village, Kertaraharja Village, toilet latrines were attended by 92 people. In this case, each participant without exception is obliged to pay periodic contributions of 20 thousand. The results from the social gathering are given to two lucky people based on the shaking that is done once a month. Next, each arisan winner will be escorted to the building material store by the facilitator to buy a toilet.

\section{Figure 1}

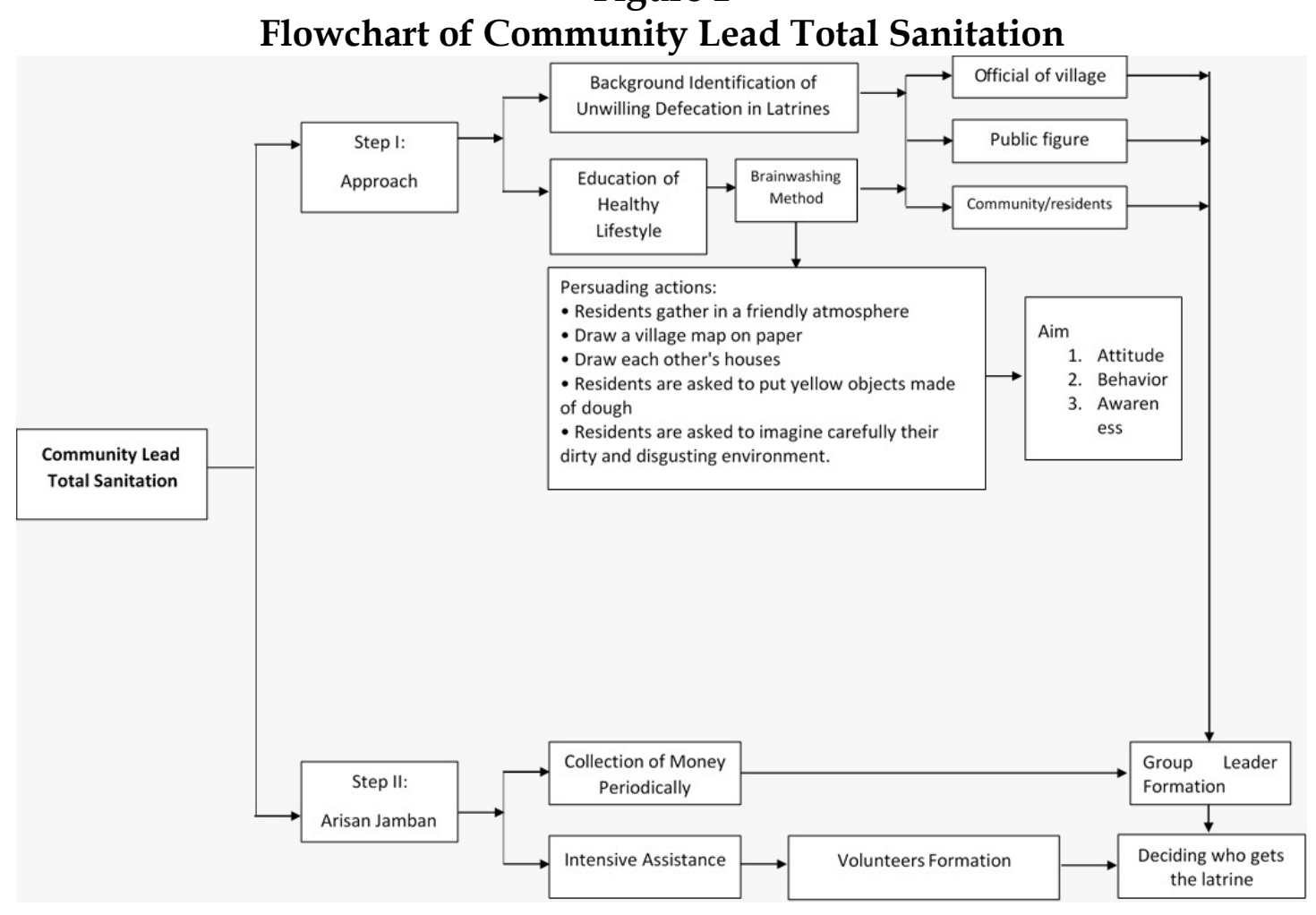

\section{Obtained Results}

The CLTS program through the arisan jamban initiated by LAZ Harfa since 2007, has succeeded in bringing about social change. The arisan jamban program using CLTS triggering method based on the community-based economic development and health project has not only succeeded in eradicating tens of thousands of people in 29 assisted villages in 8 sub-districts in Pandeglang Regency from the habit of open defecation but also at the same time empowering them to live healthier and economically empowered.

In Bulakan Village, Kutamekar Village, Sobang District, for example. Since the latrine ownership campaign has been carried out, there are now around 29 households who have succeeded in changing the behavior from open defecation to defecating using the toilet. Before the intervention program by LAZ Harfa, it was 
noted that none of the communities had latrines in their homes (https://www.bantennews.co.id/masyarakat-kampung-bulakan-pandeglangdeclarasi-henteu-ngising-sutarangan/) accessed on Wednesday 29 April 2020 at 12:15.).

Likewise in Bahbul Village in the same village and sub-district. In 2014, before the CLTS intervention by LAZ Harfa, out of 300 residents, around 70 percent had a habit of using open defecation, which was carried out either behind the house, garden, or riverbank. However, after implementing the CLTS program in the form of an arisan jamban, now all citizens have changed habits. That is no longer BABS because every house has been equipped with latrines (https:/ / banten.suara.com/read/2019/04/15/220808/ada-arisan-jamban-kiniwarga-kampung-bahbul-tak-lagi- random chapters accessed on Wednesday 29 April at 11:30).

Based on data from LAZ Harfa Research and Development, before the CLTS intervention in the 29 villages mentioned, there were at least 6,035 houses or only 23.11 percent of the total number of houses previously owned, while the remaining 20,078 houses did not have latrines. alone. However, after intervention through the CLTS program in the form of arisan jamban, there has been an increase in the number of houses that have latrines, namely 16,531 houses, or an increase of 63.31 percent, with as many as 10,496 built toilets. Thus the number of houses that do not have latrines has decreased to 9,582 homes, or an increase in the number of houses that have latrines by 40.19 percent. So, if in each house there are five family members, it means that more than 50 thousand residents have succeeded in changing the habit of open defecation, which of course has a significant impact on improving the quality of public health and the environment (https://lazharfa.org/arisan-jamban) -actionreal-realize-sanitation-healthy / Accessed on 29 April 2020 at 11.33).

Because the CLTS program is based on a spirit of empowerment, it is not only latrines that have been successfully built, but there has also been a change in the way people look at other fields, especially in the economic field, namely the emergence of their spirit of independence. The micro-economic group that is being promoted together with arisan jamban activities, has also helped build awareness, especially mothers, to empower and work in the field of food security, among others through the creation of vegetable gardens in front yards of houses to minimize the expenditure of daily household needs day. Also, through saving and loan activities, some participants in the social gathering use loans for business capital.

The arisan jamban program which has successfully broken the BABS habit is recognized by the community. They feel the benefits of this arisan jamban program. The assisted residents feel grateful for this arisan jamban program. Besides no longer defecating, they feel calmer and feel safe. The experience of open defecation, especially at night, which often causes difficulties and is faced with danger, whether because of being almost pecked by a snake or other causes, is no longer experienced.

\section{Conclusion}

Based on the findings of the research and discussion as above, the following conclusions are obtained.

First, the persuasive communication processes carried out in each phase of change as an integrated part of a healthy life campaign through the arisan jamban 
(latrine) program have quite good effectiveness in encouraging public awareness to make changes, both in terms of behavior, attitudes, and perspectives.

Secondly, this fact also proves that persuasive communication in a campaign has a strategic value to build public awareness about a matter, without imposing their will or will.

\section{About Authors}

Abdul Malik is a former journalist who is a lecturer in Universitas Serang Raya, Communication Studies Program. Besides teaching, he also likes writing. He has so many articles published in several media. Many books that have been made include Menjadi Orang Banten; Refleksi Seorang Wartawan tentang Banten (2003), Jejak Ulama Banten (2006 dan 2008) and others.

Liza Diniarizky Putri is a lecturer at Communications studies who also serves as Public Relations at Universitas Serang Raya. She has an interest in social studies, public relations, and the media. He has written several articles in scientific journals and written a book chapter titled Negara Darurat Etika.

\section{Acknowledgments}

This paper and the research behind it would not have been possible without the extraordinary support of our partners, our parents, and our friends. Their enthusiasm, knowledge, and attention to detail have inspired me and my work at our first meeting with books on Social Instruction.

\section{References}

Bantenheadline. (2020). Ratusan Ribu Rumah Tangga Di Pandeglang Masih 'Dolbon'. April. https:/ / bantenheadline.com/ratusan-ribu-rumah-tangga-di-pandeglangmasih-dolbon/.

Bantennews. (2019). Masyarakat Kampung Bulakan Pandeglang Deklarasikan "Henteu Ngising Sembarangan". Desember. https:// www.bantennews.co.id/masyarakatkampung-bulakan-pandeglang-deklarasikan-henteu-ngising-sembarangan/.

Cangara, Hafied. 2014. Pengantar Ilmu Komunikasi. Jakarta: PT. Raja Grafindo Persada.

Denzin, Norman K \& Yvonna S. Licoln. 1994. Handbook of Qualitative Research. London: Sage Publications.

IDN.(2020). Turun, 4.310 Balita di Pandeglang Masih Alami Stunting. April.

https:// banten.idntimes.com/news/banten/khaerul-anwar-2/turun-4310balita-di-pandeglang-masih-alami-stunting/full.

Laz Harfa. (2019). Masyarakat Kampung Bulakan Pandeglang Deklarasikan "Henteu Ngising Sembarangan". (April). https://lazharfa.org/masyarakat-kampungbulakan-pandeglang-deklarasikan-henteu-ngising-sembarangan/.

Laz Harfa. (2020). Arisan jamban Aksi Nyata Wujudkan Sanitasi Sehat. April. 
Volume 2, Issue 2, August 2020

http://hk-publishing.id/ijd-demos

https:// lazharfa.org/arisan-jamban-aksi-nyata-wujudkan-sanitasi-sehat/.

Moleong, Lexy J. 2007. Metodologi Penelitian Kualitatif. Bandung: Remaja Rosda Karya.

Mulyana, Deddy. 2003. Ilmu Komunikasi Suatu Pengantar. Bandung: Remaja Rosdakarya.

Percik, Media Informasi Air Minum dan Sanitasi. Edisi 01 Tahun k3-10, Agustus 2012.

Ruslan, Rosady. 2008. Manajemen Public Relations dan Media. Jakarta: PT. RajaGrafindo.

Suara. (2019).Ada Arisan Jamban Kini Warga Kampung Bahbul Tak Lagi BAB Sembarang. April. https://banten.suara.com/read/2019/04/15/220808/adaarisan-jamban-kini-warga-kampung-bahbul-tak-lagi-bab-sembarang.

Venus, Antar. 2009. Manajemen Kampanye. Panduan Teoritis dan Praktis dalam Mengefektifkan Kampanye Komunikasi. Bandung. Simbiosa Rekatama Media.

Wuryanto. 2014. Pengantar Ilmu Komunikasi. Jakarta: Grasindo. 